\title{
ACHIEVING THE SUSTAINABLE DEVELOPMENT GOALS
}

\author{
Aurel Constantin LUPU, Oana Raluca IVAN \\ "1 Decembrie 1918" University of Alba Iulia, Alba Iulia, Romania \\ aurel.lupu@uab.ro \\ raluca.ivan@uab.ro
}

\begin{abstract}
The purpose of this paper is to examine the state of Romania's sustainable development using statistical indicators (green investments, employment rate, GDP expenditure on research, development, and innovation, greenhouse gas emissions, share of renewable energy in gross final energy consumption, early school leavers, tertiary educational attainment, and people at risk of poverty or social exclusion). The method used in this research work is bibliographical and statistical research. The topic of sustainability has experienced a new upswing. Society demands sustainable business from companies and wants transparent information in return. The importance of sustainable action is also reflected in investment decisions: the classic financial key figures are no longer the exclusive reason for an investment. Rather, non-financial indicators are expected to provide further information about the long-term value of a company. In 2014, EU member states adopted a directive to expand the reporting of large capital market-oriented companies, credit institutions, financial services institutions and insurance companies. Since 2017, this Nonfinancial Information (NFI) Directive has been mandatory for capital market-oriented companies in Austria within the framework of the Sustainability and Diversity Improvement Act (NaDiVeG). In concrete terms, this means that capital market-oriented companies must publish a non-financial statement or a separate non-financial report in addition to the management report. The number of companies generating and providing non-financial information to interested users is steadily increasing around the world, while the quality of disclosure of such information is increasing. Year by year, as evidenced by numerous studies and stakeholder surveys. In Romania, green initiatives have resulted in an increase in the share of renewable energy in total energy consumption, a decrease in school dropouts, and an increase in the number of students enrolled in bachelor's degree programs.
\end{abstract}

Keywords: non-financial reporting; sustainable development; disclosure; regulations; performance indicators; stakeholders.

JEL classification: B55, F63, F64 


\section{Introduction}

The evolution of non-financial reporting may be seen in all of the EU's member countries. The new regulations' main goals are to improve information transparency of the results of companies' activities on society and the environment, strengthen organizations' reputations, and increase confidence in their commercial activities; and to systematize the process of introducing public non-financial reporting. It is important to keep an eye on company annual reports, which include metrics that describe the social and environmental elements of their operations.

I highlight the most well-known and widely used GRI (Global Reporting Initiative) standards and conceptual frameworks for integrated IR (Integrating Reporting) reporting, despite the fact that there are a large number of international and national corporate reporting standards that form requirements for the disclosure of various aspects of sustainable development.

Furthermore, in light of current trends in the development of issuing company reporting, as well as the increased focus on stable development factors, it is necessary to highlight the practice of developing American standards in the field of Sustainability Accounting Standards Board Standards (SASB Standards). It governs disclosure requirements for companies whose shares are listed on the US stock exchange; a special initiative Despite the presence of common approaches, the standards under consideration have significant differences in terms of both the target audience and the requirements for the content of the disclosed information, accounting for industry features, and other important factors to consider when selecting a governing framework for the development of corporate reporting.

Organizations should build a set of key performance indicators (KPIs) that correspond to each of the aforementioned areas in order to achieve the sustainable development goals. The scorecard's development outcomes might be presented in the form of a table. In the establishment of a system of key performance indicators, both quantitative and qualitative indicators are employed. Quantitative indicators of long-term development can be both financial and nonfinancial in nature. Quantitative non-financial indicators include the number of jobs created, the number of employees who have undergone or will undergo retraining, will increase qualifications, will enter a new profession, will reduce the number of jobs with hazardous working conditions, occupational diseases and injuries, and the volume of emissions, discharges, and waste.

The capital and operating expenses of the organization related to environmental activities, as well as the corresponding monetary benefits from them are examples of cost (financial) indicators. For example, the growth of revenue from the sale of certified environmentally friendly products, the creation of new brands, the growth of energy efficiency, the reduction of payments for excess discharges, emissions of pollutants in the environment; fines are examples of cost (financial) indicators. The use of quantitative indicators allows for comparisons in the dynamics as well as with other firms' similar indicators. 
Qualitative indicators of sustainable development are used to assess the degree of achievability of a specific result, such as the quality of life, employee satisfaction, product compliance with world scientific and technical standards, and so on, as well as for the analysis of non-financial strategies, such as regulatory, operational, social, environmental, and reputational strategies. Traditional units can be used to quantify qualitative markers of sustainable development (points, coefficients and ratings.

\section{Research methods}

This research paper's technique consists of bibliographical and statistical research. The current state of the art in the topic of sustainable development is covered in the bibliographical research. The statistical data collecting is covered by statistical research. Eurostat data was used to compile the study's data, which was then processed and evaluated.

The data is provided in statistical tables, which is a means for describing the indicators that the completed analysis is based on, as well as creating existing links between its component pieces. Graphical representations have been used to highlight the scope and/or variance of data submitted to statistical study in order to demonstrate their progression through time. We offer an innovative approach to assess Romania's condition of sustainable development (Table 1). The suggested methodology for assessing Romania's sustainability is based on Gogan and Draghici's model from 2013 [1]. The following are the characteristics of the suggested model for evaluating and analyzing Romania's sustainable development:

Examining Romania's present condition in terms of sustainable development in comparison to the European Union;

establishing goals for putting the country on a sustainable path;

Highlighting the adjustments that are required for long-term sustainability;

Determine the resources available or required for long-term growth;

Sustainable development is incorporated into economic and financial reports (at national and organizational level).

Creating a framework for long-term development. This will not only build a dynamic strategy, but it will also entail a continual improvement process in order to turn sustainable development into financial advantages.

Perspectives are being assessed. The suggested model takes into account the three pillars of sustainable development: the economic, the environment, and the social. Each of these pillars has two or three indicators that allow us to compare the condition of sustainability in Romania to that of the European Union (28 countries).

This paradigm allows for cross-country comparisons while concentrating on the dynamic of sustainable development. 
Table 1: Key performance indicators on sustainable development

\begin{tabular}{|l|l|}
\hline Significant aspects & Key Performance indicators \\
\hline Economy & $\begin{array}{l}\text { Employment rate } \\
\text { Gross domestic product } \\
\text { Gross domestic Expenditure on research and innovation }\end{array}$ \\
\hline Environment & $\begin{array}{l}\text { Greenhouse gas emissions } \\
\text { Share of renewable energy in gross final energy } \\
\text { consumption }\end{array}$ \\
\hline Social & $\begin{array}{l}\text { Early leavers from education } \\
\text { Tertiary educational attainment } \\
\text { People at risk of poverty }\end{array}$ \\
\hline
\end{tabular}

Source: Developed by the author

\section{Findings}

In Romania, the green economy is linked to long-term growth. Romania has taken some important efforts in the transition to a green economy by developing policies in crucial sectors such as the National Strategy for Sustainable Development 2030. Over the period 2014-2020, Romania received EUR 30.8 billion through eight national programs, amounting to an average of 1.548 euros per person. The breakdown of investments from structural and cohesion funds and with national cofinancing on axes of intervention is presented in Figure 1.

Green initiatives in Romania have resulted in an increase in the share of renewable energy in total energy consumption (19\% in 2021), a decrease in school dropout (15.3\% in 2019), and an increase in the number of students enrolled in bachelor programs amounted to 27,111 in the school year 2019-2020. This represented a growth of approximately 25 percent compared to the academic year 2014-2015. The job situation in Romania is problematic. Romania has lost 23.3 percent of its working-age population owing to emigration during the last three decades, 17 resulting in a 0.6 percent to 0.9 percent decline in annual GDP growth. Over 3 million people are said to have fled the nation, with a considerable number of highly skilled individuals among them.

Romania's population is expected to fall by 22 percent by 2050, the steepest projected global decline, due to a combination of emigration, high mortality, and low birth rates, according to the Ministry of Health. Demographers estimate that Romania's population will fall by 22 percent by 2050 , the steepest projected global decline, due to a combination of emigration, high mortality, and low birth rates. At least three steps are necessary to improve the situation:

Targeted activation strategies and integrated public services should be strengthened, with a focus on those who are the most excluded from the labor market.

Make education a top priority. Instead of the existing 3.7 percent, allocate $6 \%$ of GDP to education.

Ensure that there is a deeper commitment to collaboration and multi-stakeholder partnerships, particularly at the grassroots level. 


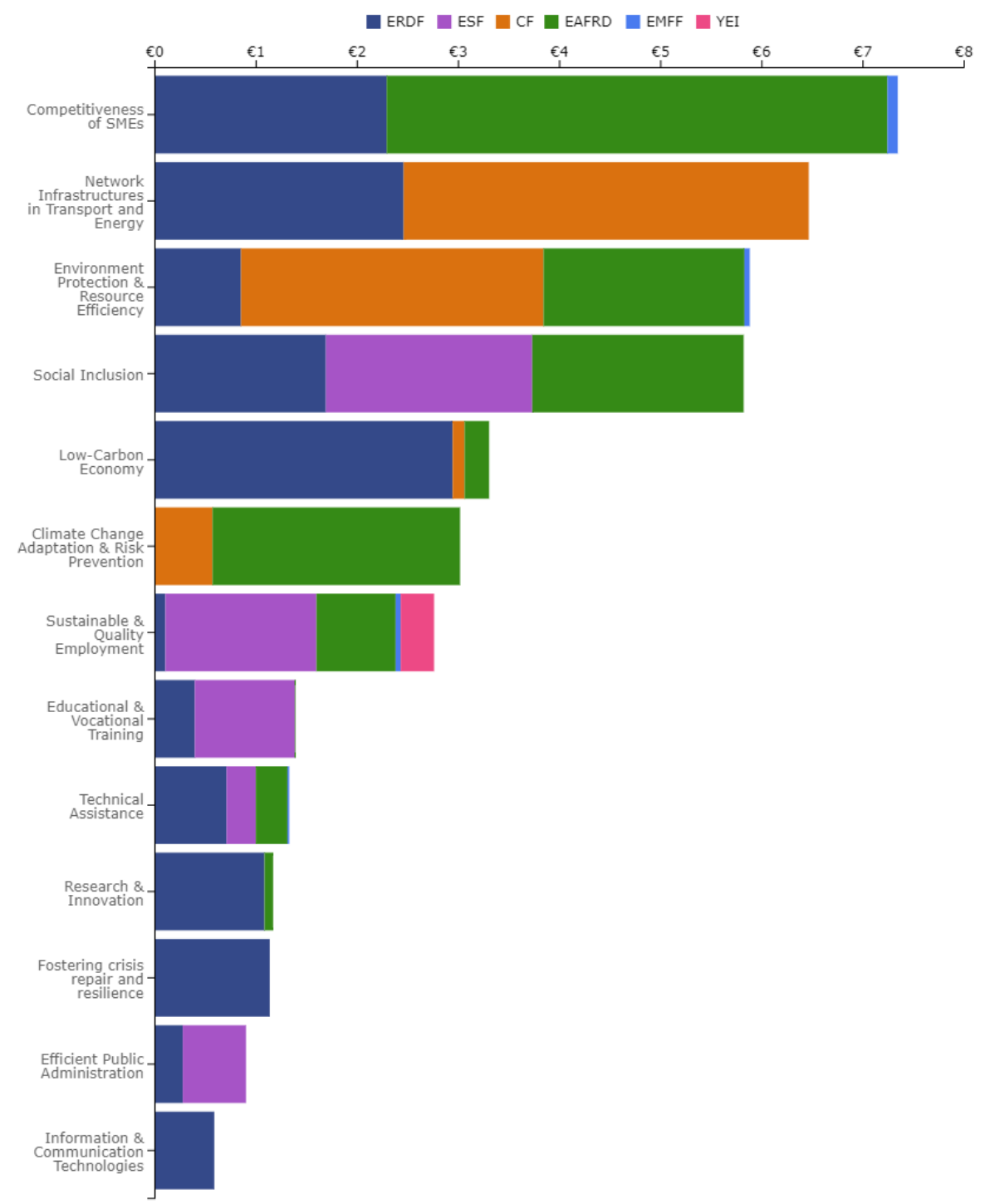

Figure 1: Total budget in Romania, billion Eur

Source: https://cohesiondata.ec.europa.eu/countries/RO

ERDF - European Regional Development Fund

ESF - European Social Fund

YEI - Youth Employment Initiative

CF - Cohesion Fund

EAFRD - European Agricultural Fund for Rural Development

EMFF - European Maritime \& Fisheries Fund

Romania needs to keep implementing renewable energy projects and steps targeted at updating the road transportation sector, as well as launching a carbon capture and storage (CCS) project and a forestry program. Romania must also improve the delivery of the green certificate program, provide financial assistance 
for renewable energy projects, and take measures to increase the capacity of renewable energy power and heat generation. It is not too late to change the current unsustainable development trajectory. This necessitates not just study, but also education, participation, and increased concerns about alternative civic obligation as well as political bravery.

If we look in the Figure 2, we can observe that Romania took initiatives from 2008 until 2019 to improve in most of the areas besides research and development expenditure and early leavers of from education and training. These two areas are critical, and a concrete strategy is needed to reach national targets. A good thing is that from 2008 until 2019 the number of people at risk of poverty or social exclusion decreased and it goes beyond the national targets set. Romania must continue with programs in this area considering the pandemic situation which can lead to an increase of poverty.

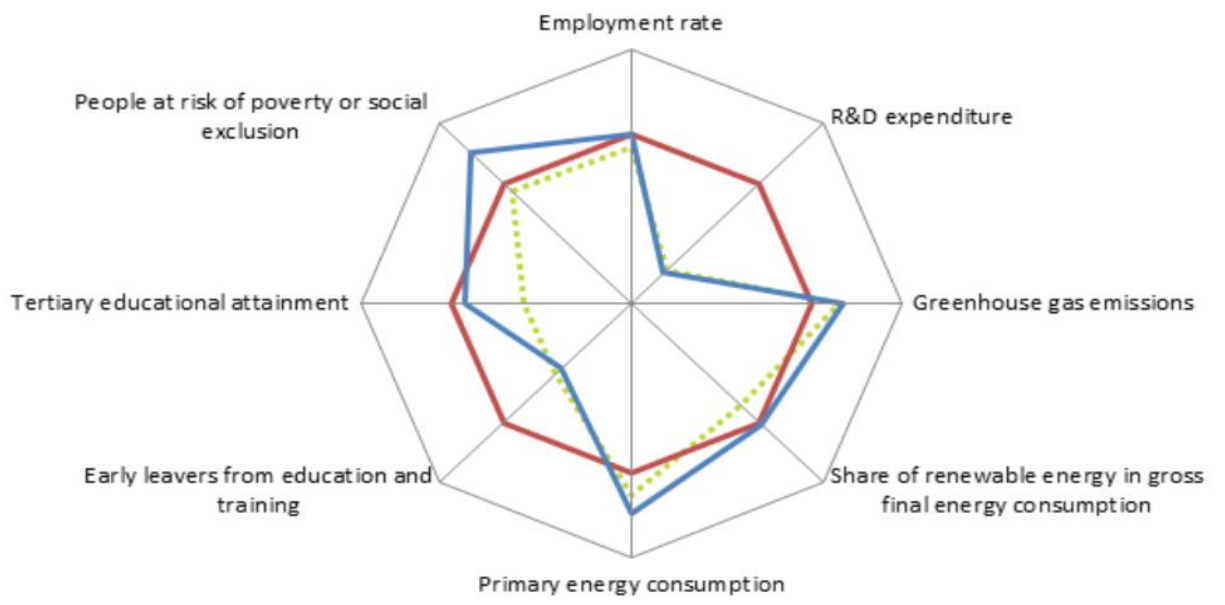

:2008 D National Target DMost recent data

Figure 2: Change since 2008 in relation to national targets, 2019 Source: Eurostat statistics

\section{Conclusion}

For many businesses, developing public non-financial reporting that takes into consideration best practices and international standards is a relatively new task, which inevitably leads to challenges in practice.

To address them, it is necessary to collect, compile, and share experiences in a format that is accessible to a broad range of stakeholders: in the form of specialized reviews and publications in professional journals; the organization of meetings, open dialogues, webinars, and other activities for the exchange and discussion of experience. 
Natural resources are in threat under current conditions, yet green solutions for long-term growth may be produced via research and innovation. Increasing employment, reducing carbon emissions, raising the share of green in total consumption, energy efficiency, lowering the dropout rate, reducing poverty, and increasing the rate of graduates are all examples of sustainable development. Sustainable development is achieved by the creation of a competitive economy, a green economy, and the stimulation of green investments in the three pillars of sustainable development: environment, economy, and society. Because Romania's unemployment rate is lower than that of the European Union, the country has to engage in new job creation. New jobs can be created through green investments and the development of new sustainable businesses. Romania has taken significant steps toward long-term growth, and she recognizes that the only way out of the crisis is via long-term development.

Future growth should be intelligent, long-term, and inclusive. The world, according to sustainable development, should be viewed as a system made up of three key components: society, environment, and economics. These components are interdependent, meaning that any change in one induces changes in the other two. Sustainable development entails ongoing expansion that does not degrade living quality, and society should be greener tomorrow than it is now.

Romania faces a dilemma in terms of sustainable development, due to the lack of a sustainable development model. The four methods that comprise the basic mechanism of sustainability are sustainability management, sustainable innovation, sustainable eco-efficiency, and obtaining and preserving sustainable competitive advantages. A model of sustainable development suitable in Romanian society will be constructed on the foundation of these four sustainable development methods.

\section{References:}

1. European Commission (2011), Roadmap to a Resource Efficient Europe. In: communication from the Commission to the European Parliament, the

2. Council, the European Economic and Social Committee and the Committee of the regions, Brussels, 2011.

3. Pauli GA (2010), The blue economy: 10 years, 100 innovations, I (H) million jobs. Paradigm Publicatioms; 2010.

4. European Environment Agency (2013), Towards a green economy in Europe, EU environmental policy targets and objectives 2010-2050. In Report no .8/2013.

5. Eurostat (2013), Smarter, greener, more inclusive? In Eurostat Statistical Book, 2013.

6. European Commission (2010), Skills for green jobs. In European synthesis Report, 2010.

7. RIDS. About sustainability (report in Romanian language). In Report of the Romanian Institute for Sustainable Development; 2014.

8. European Environment Agency (2012), Ecosystem resilience and resource efficiency in a green economy in Europe. In Environmental indicators report, 2012.

9. UNEP. Towards a Green Economy: Pathways to Sustainable Development and Poverty Eradication, 2011.

10. Ocampo J.A. (2005), Beyond Reforms: Structural Dynamics and Macroeconomic Vulnerability. In the Quest for Dynamic Efficiency: 
Structural Dynamics and Economic Growth in Developing Countries, Stanford University Press; 2005.

11. Trica C.L., Papuc M. (2013) Green economic grow the premise for sustainable, In Theoretical and Applied Economics, Volume XX (2013), No. 1(578), pp. 131-140.

12. Dima B., Dima S.M., Lobont O.R.(2013), New empirical evidence of the linkages between governance and economic output in the European Union

13. in Joumal of Economic Policy Reform, Volume 16, Issue I, 2013, pp. 68-89.

14. Lobont OR. New altemative possibilities for measuring poverty in Romania in Cross-Cultural Management Journal, Volume XV

15. Lobont O.R., Nicolescu A. C. (2012), Controversies and Perspectives on Public Sector Performance Measurements, Analele Universitätii Ovidius

16. Constanta. Seria: Stiințe Economice, Volume XII, Issue 2, 2012, pp. 11991203

17. C. Popovici, Geurt van de Kerk, A. Manuel (2009), Regional Sustainable Society Index, RSSI. Romania, on its way to a sustainable society, 2009.

18. Gogan, L. M., Draghici, A (2013) A model to evaluate the intellectual capital. Procedia Technology, Vol. 9, 2013 pp.867-875.

19. European Commission (2013), Operational Programme "Environment" Programme under Convergence objective co-funded by European

20. Regional Development Fund (ERDF) and the Cohesion Fund (CF), 2013

21. National Institute of Statistic (2014), Sustainable Development Indicators, 2014.

22. Draghici, A, Fistis, G., Sirbu, R, Draghici, G. (2014), Leadership In Sustainability—An Opportunity For Green Skills Developement in Romania, 2014, pp. 1043-1050.

23. Jackson, S. E., Renwick, D. W., Jabbour, C. J. \& Muller-Campn, M. (2011). State-of-the-art and future directioms for green human resource management: Introduction to the special issue. Zeitschrift flir Personalforschung (ZtP), 25(2), 99-116.

24. Luna, H., Martin, S., Scott, W., Kemp, S., \& Robertson A. (2012), Universities and the green economy: graduates for the future. Higher Education Academy, UK, 2012.

25. Pronk J (2012), Millennium Development Goals to Sustainable Development Goals, In: The 2012 International Symposium on Cultural Diplomacy 